\title{
sciendo
}

\section{InTERnATIONAL COURT JURISDICTION IN DisPUTES CONCERNING UNLAWFUL USE OF TRADEMARKS ON THE INTERNET}

\author{
Tomáš Gongol ${ }^{1}$, Radka Zahradníková ${ }^{2}$
}

\begin{abstract}
The rapid development of IT technologies in the last few decades has also created increasing number of cross-border disputes. This trend is affected by the fact, that there are no border lines that we can find in the real world. Different law systems have to deal with the existence of this new, on state borders independent entity. In the perspective of law, internet is interesting because of its inability as a virtual space, to fit in the doctrine of legal state, by which the state exercises its authority and enforces its law on its territory. This traditional bond between the state, its territory and its law system is impaired, sometimes it is referred to as virtualization or delocalization of legal relationships. Delocalization has a great influence on determination of the decisive law system and court jurisdictions. In those cases, we need to distinguish substantive law and procedural law in order to determine court (or other institution) jurisdiction and law system which would be applied on the case. With regard to the topic of this article, we will deal with private law relationships with international elements. Unlawful use of trademarks on the internet raises a number of issues. One example is the use of trademarks on the internet and to what extent such use is infringing trademark rights on a specific territory. This paper deals particularly with the jurisdictional issues and how rules on private international law can assist in resolving these issues. The currently applicable EU Brussels I Regulation (Recast) allows infringers to be sued either in the place of the defendant's domicile or in the place of the harmful event.
\end{abstract}

\section{Keywords}

Court Jurisdiction, European Union, Internet, Trademarks

\section{Introduction}

With the emergence of the Internet, the enforcement of cross-border infringements concerning unlawful use of trademarks on the internet has become highly relevant.

\footnotetext{
${ }^{1}$ Silesian University in Opava, Univerzitní náměstí 1934/3, 73340 Karviná, Czech Republic.

E-mail: tomas.gongol@slu.cz.

${ }^{2}$ University of West Bohemia, Univerzitní 8, 30614 Pilsen, Czech Republic.

E-mail: radka.zahradnik@gmail.com.
} 
Therefore, the determination of particular jurisdiction in disputes concerning unlawful use of trademarks on the internet is a current and burning topic. The question addressed in this paper is what jurisdiction has to be chosen in order to ensure both the effective enforcement of trademark law online and sufficient protection of legitimate interests of users.

After the internet became a worldwide phenomenon, theorists were trying to answer a question of how to regulate it by law. Two main theoretical concepts were created. Goldsmith (1998) is a representative of a cyber-paternalistic concept. Goldsmith's concept is based on not making a difference between the real world and a virtual one. According to Goldsmith, everything is about communication of existing individuals whose location is always known. In conclusion, this concept is based on application of law according to location of acting (communicating) individuals. If the law cannot be applied directly to the acting person, Goldsmith states, that the law should be applied to the person who is indirectly involved, such as internet connection provider, hardware or software manufacturer etc. In case that the subject has a branch office or other property in that state, law can be also applied to him. Goldsmith distinguishes between scope of a legal act and an enforcement of a legal act. This approach leads to extraterritorial effectiveness of law and Goldsmith compares it to air pollution, which destroys the environment not only in a state that produces it, but also its neighbors. For determining court jurisdiction, he has created a concept of so-called substantial effect, according to which, act can be regulated wherever it can create such effect. Lessig (2006) has a similar view. He understands internet user as a subject over which has a full jurisdiction not only state law, but also rules of cyberspace created by the users themselves. Johnson and Post (1996) represent a different opinion. They propose creation of a new approach for dealing with relations on the internet. In their opinion this new approach is needed because of the specific nature of internet as a tool capable of transferring double-sided information regardless of state borders. Unlike Goldsmith, they reach conclusion that the court jurisdiction cannot be examined by substantial effect criteria on the territory of the affected state. Johnson and Post state, that the relationship between the two communicators can have an impact everywhere, so every court of every state could claim its jurisdiction. This situation cannot be acceptable, because it would create the unreal criterion that everyone would have to be familiar with every law system in the entire world in order to share an information on the internet (there could be potential unjust effect committed everywhere).

In accordance with cyber-libertarian concept, Johnson and Post propose a different approach when regarding the internet. In their opinion, internet is a territory sui generis, so called cyberspace, which should be governed by its own law system based on a contract called cyberlaw, with its citizens named netizens. These ideas have a direct effect to determining court jurisdictions, therefore to extensive, restrictive and moderate approach to dealing with this problem (will be discussed later).

In conclusion, cyber-paternalistic and cyber-libertarian conceptions form an opinion on a question, whether on transactions made through the use of internet should be applied the same rules as to those in the real world or society has to create its own set of rules made specially for this purpose. 


\section{International court jurisdiction in disputes concerning unlawful use of trademarks on the internet}

In the real world, due to a unique nature of a dispute, courts sometime have to deal with a conflict of two law systems. This happens all the more in the internet environment, which enables creation of an international element more easily thanks to fast communication. In many cases, the application of a border determinant in disputes regarding internet is the same as in the regular cases. Examples of such determinants can be residency, place of business of subjects that conclude a contract. Due to delocalization of legal relations, more problematic is determining a "place where the harmful event occurred or may occur" (see article 7 paragraph 2 of a Regulation (EU) No 1215/2012 of 12 December 2012 on jurisdiction and the recognition and enforcement of judgements in civil and commercial matters), which is important to violations of a trademark rights. Placing an information, for example foreign trademark, on a website in one country can cause harm to its owner in other country. This is not just an illustrative example; this situation was a subject of multiple litigations which will be discussed later. Typical for international private law is significant connection with border determinants used in the real world, due to that, their application in disputes connected with activity on the internet is very complicated. This leads to all kinds of proposals, how to deal with this situation and reform a current law. Apart from traditional border determinants, new ones were created, adapted to virtual environment. Typical example can be "location of a server" (Svantesson, 2012) providing a specific service. Authors of this article think, that this border determinant is not a good tool to improve a current situation, because between server and a matter in dispute is no deeper connection, other than that the information is located on the server itself. From this technical relation, vital legal consequences such as international court jurisdiction or decisive law cannot be implied. Also, it is not a big problem to move the content of the server which is a matter in dispute, in case the court jurisdiction would be established using this border determinant. Other alternative border determinants represent location where the information was uploaded to a server, or location where the information was downloaded (see ruling of a High Court of Australia in Dow Jones \& Company Inc. vs. Gutnick from 2002). In current judicial practice (see further) the new criteria did not apply often, courts usually adapt current border determinants on internet conditions. American and European judicial practice accepted the necessity of adapting current border determinants in spirit of Johnsons and Posts approach. Key for determining court jurisdiction of follow up problems is forum of a dispute (Rozehnalová, 2010), from which implies application of civil proceeding rules, conflicting rules of law and mandatory rules etc. Application on relations emerging on the internet developed from extensive approach to approaches more moderate built on finding a particular connection between the court of a country and actions on the internet. Above mentioned court rulings declare development in establishing international court jurisdiction in litigations over use of trademarks on the internet. 


\section{Core principles in judicial rulings in the world}

\section{SG 2 v. Brokat Informations systeme GmbH (France)}

Known, but also criticized is a dispute over a "payline" trademark, judged by a French appeal court in Nanterre on 13th of October 1996. French company SG2 was requesting a precaution against a German company Brokat based in Stuttgart. SG2 demanded that Brokat had to stop using the word "payline" on their website brokat.de that was available in France. For same kind of services, there were two separate trademarks registered, in France, and Brokat-payline in Germany (French company registered their trademark sooner). French appellate court reached conclusion, that the place where damage occurred is France, because, service provided by Brokat Company on their website brokat.de, was accessible in France even though, the website was in Germany and was meant to be used only by Germans. French court pronounced a judgement in which he had forbidden Brokat from using payline trademark in any form, including internet in France.

This judgement is an example of an extensive approach to litigations of unlawful use of trademarks on the internet. Similar examples of an extensive approach include judgement of a French court in litigation of Licra vs. Yahoo! or ruling of an Australian court in litigation of Dow Jones \& Company Inc. vs. Gutnick.

Stated court judgement leads to conclusion that almost every court in a country connected to internet can be suitable for a trial. This approach would eventually lead to restraint of use of internet for commercial purposes.

Responding to criticism of an extensive approach court rulings that came later more or less examined bond of a state where a trademark was registered and its use on internet. Nonetheless, this bond can be examined differently in each individual state.

\section{Playboy Enterprises Inc. v. Chuckleberry (USA)}

New York district court made an argumentation shift in regard of link between the object of a dispute and state itself with his judgement in Playboy Enterprises Inc. v. Chuckleberry from 1996. Publisher of an Italian magazine called Playmen published the same trademark on Italian website. In order to access the photographs, user would have to type in his user name and password, and a distinct difference was made between free version and the one user would have to pay for. Plaintiff, in this case Playboy Enterprises Inc. made an argument that defendant is violating his rights as an owner of a Playboy trademark by providing this online service. This was not the first dispute over the Playboy trademark, in 1981 distribution of a Playmen magazine was banned from USA market based on a violation of Playboy trademark rights. According to plaintiff, defendant was obliged to improve password entering process to a payable version, so that the user from USA could not get in. This was to be done by a credit card recognition system. Similar method was to be done with photograph access, using an IP address source recognition system. Court came to a conclusion, that nobody can be banned from creating a website under certain name just because it can be accessed in a state which prohibits selling a product due to a violation of owners' rights to a trademark. 
Main trend in all the court judgements, both American and European, is a deflection from extensive concept of court jurisdiction to a concept, which seeks a bond between the dispute or a defendant and a state. In previous cases the key to establish US court jurisdiction was presence of a defendant on US territory. To 1945 all that was necessary was delivery of a summoning to a defendant, who was present on a territory of the state (Akehurst, 1972). That changed with court ruling in International Shoe Co. vs. Washington, which established a doctrine of so called "minimal contact". There are many interpretations of a minimal contact doctrine, for example as a relevant legal proceeding, residence or existence of a commercial representation on the relevant territory (Mills, 2009) and application of its doctrine was later extended to an international litigation. Accept from a condition of a minimal contact courts are viewing possibilities on how to deliver a note of commencement of litigation and a fulfillment of conditions for court jurisdiction consistent with civil proceedings of a place where litigation takes place.

\section{Zippo Manufacturing Company v. Zippo Dot Com}

As we saw in previous cases, core of this dispute from 1996 was unlawful use of trademarks on the internet. District Court for the Western district of Pennsylvania created a scale used for determination, whether the website fulfills the description of minimal contact or not, which was curtail for court jurisdiction. The court concluded that curtail criteria for court jurisdiction is level of a business activity on the internet by the defendant. The court established three scenarios:

* Active website: defendant is actively doing business on the internet, using his website, negotiates contracts with foreign state citizens. Those cases establish court jurisdiction.

* Passive website: defendant placed information on his website with the sole purpose of making them public. Even thought, these information's, are accessible from a foreign country they do not allow customer to establish a contract. Those cases do not create the individual court jurisdiction.

* Interactive website: those cases are a combination of the previous two. Website allows interactive exchange of information between website and a user, and by extent and nature of those interactions court states whether his jurisdiction is established or not.

Svantesson (2016) states that this scale can be used to this day in the intellectual property area even though websites (especially in online shopping) are more and more interactive. Nonetheless, the website development and a problem, with establishing a level of interactivity was later criticized and led to abandoning so called Zippo scale not only in internet shopping area.

Later development led to addition of another "tests", such as "effects test" used by US Supreme court in Calder v. Jones from 1984. This approach states that court jurisdiction is established if defendant acted willfully, realizing the consequences. Another example is so called targeting test (Wang, 2010) which means targeting harmful consequences done by a defendant to a plaintiff who knew, that the defendant is a citizen of a country where the 
trial takes place and where he was doing business. Nowadays, we can find a combination of above-mentioned objective or subjective criteria in the judicial practice of American courts especially in regard of targeting test whose purpose is to clarify the intentions of a defendant regarding his business on a territory of a state and its citizens (consumers).

\section{Legislation of a territorial jurisdiction in internet disputes in EU}

Crucial for this area is Council Regulation (EC) No 44/2001 on jurisdiction and the recognition and enforcement of judgements in civil and commercial matters (Brussels I.) and its recast Regulation (EU) No 1215/2012 of the European parliament and of the Council on jurisdiction and the recognition and enforcement of judgements in civil and commercials matters (Brussels I. bis). Authors of this article are also mentioning the older version because of its relevance to important judgements of the Court of Justice of the European Union. Stated regulations are establishing court jurisdiction first by stating general jurisdiction (article 2 of Brussels I and article 4 of Brussels I bis) and cases when special jurisdiction applies (article 5 Brussels I and article 7 Brussels I bis). Principal of a general jurisdiction can be applied when defendant has a place of business or residence on territory of the EU. The nationality is not a key factor. In some cases, it is appropriate not to use general jurisdiction rule but use a rule that is due to its nature, the closest to the relevant case (Rozehnalová and Tyč, 2003). This approach is known as a special or alternative jurisdiction. Reflecting the nature of this article and therefore concentrating on violations of rights to intellectual property, special (alternative) jurisdiction rule can be for example article 5 paragraph 3 regulation Brussels I (article 7 paragraph 2 Brussels I bis) "in matters relating to tort, delict or quasi-delict, in the courts for the place where the harmful event occurred or may occur". Interpretation of a word "place" regarding actions on the internet, will be explained in the next chapter discussing rulings of Court of Justice of The European Union.

To complete the subject, we will add interpretation of article 5 paragraph 5 regulation Brussels I (article 7 paragraph 5 Brussels I bis) which states following: "as regards a dispute arising out of the operations of a branch, agency or other establishment, in the courts for the place in which the branch, agency or other establishment is situated". The key aspect of this discussion is term "branch" meaning other agency or other establishment which has no legal personality. Court of Justice of the European Union defined key elements of this term in judgement Somafer SA against Saar-Ferngas AG, from 1978 (C-33/78), those are:

* Permanent nature

* Own business leadership and material assurance

* Ability to negotiate with a third party on its own

* Subjected to control by a parent company

Regarding subject of this article, we can ask ourselves, whether we can consider website to be a branch. Business owner, doing his business through this virtual space does not have to have an actual shop to fulfill his line of business. If yes, does that mean that availability of a website in a certain country mean also jurisdiction of its procedural and private law? 
There are opinions of extensive interpretation and also opinions completely different. The protagonist of an extensive approach Polčák (2007) states that website, accessible under particular domain can be considered to be a branch because of its fulfillment of criteria stated above. On the contrary Svantesson (2016) states that because of lack of a link between website and specific a country, webpage cannot fulfill the criteria, thus it cannot be considered as a branch.

In accordance with older rulings of the Court of Justice of the European Union (for example Bier v. Mines de Potasse d'Alsance publ from 1976 (C-21/76)) it is necessary to consider "place where harmful event occurred" to be a place, where negotiation which led to the harmful event occurred. This interpretation enables plaintiff to defend violations of his subjective rights and also claim different thing in multiple different courts, e.g. trademark rights, unfair competition (Bogdan, 2011).

Undermentioned judgements represent attitude of the Court of Justice of the European Union on localization of the activity, respectively its consequences on the internet.

\section{Important judgements of CJEU}

\section{Peter Pammer v. Reederei Karl Schlüter GmbH \& Co KG (C-585/08)}

The subject of interpretation of judgement of CJEU in Peter Pammer v. Reederei Karl Schlüter $\mathrm{GmbH}$ \& Co KG from 2010 (C-585/08) was article 15 paragraph 1 letter c of Regulation Brussels I, specifically question, under what circumstances a businessman, who's activity is presented on his website or on a website of his provider, can be considered as a businessman focusing his activity on member state of the EU, in which consumer is residing. In order to determine this, would it be enough that the website can be accessible on the internet?

CJEU assessed this question based on a comparison between normal advertisement and an internet one. With normal advertisement (spread by newspapers, television, radio, cinema, catalogs etc.) a considerable amount of money comes, that has to be invested by the businessman in order to become publicly known in other member states and that also proves his intention of expanding his business to other member states. On the other hand, this intention could be absent when it comes to advertisement via the internet. Due to its nature, the internet is a worldwide communicator and advertisement placed on internet can be accessible in all the countries around the world, thus in the entire EU without any other expenses paid for the advertisement that would affect consumers outside of the member state, where the business has its headquarters.

CJEU made a conclusion that when interpreting a phrase "action aimed" cannot come to the conclusion that these actions are related to accessibility of a website in other member states, where the businessman has his headquarters.

The court has to examine every case if there are indications which would prove, that the businessman had intention of doing business with consumers that are residents in other member states of the EU. CJEU stated key factors to determine: 
* Explicitly stating that he is providing services in one, or more named member states

* Investing in a service of sponsored links enabling him to simplify access for customers residing in other member states to his website

* Activity has an international nature, for example travel agency etc.

* Stating a number with international prefix on his website

* Using first class domain other than the domain of a member state, in which the businessman has his headquarters or using other first-class domains such as "com" or "EU"

* Stating an international clientele consisting of customers residing in other member states

* Description of a route to a place of business with starting point in other or multiple member state (s)

* Stating an international clientele consisting of customers residing in other member states especially with evaluation possibilities

* Enabling customers to use their own language or currency if they are different from stated language or currency

On the contrary, CJEU does not consider sole accessibility of a website abroad or stating a foreign electronic or geographic address of a businessman or stating a phone number without a foreign prefix to be key factor.

\section{eDate Advertising v. X a Oliver Martinez, Robert Matinez v. MGN Limited (C-509/09 a C-161/10)}

Both cases are legal actions to prove alleged violation of protection of person. The basis of their lawsuit was a claim, that defendant was publishing information liable to special law protection (such as criminal charges, private information etc.) on informational websites of publishers with headquarters in other member state, then the injured party. In those cases, it is essential to determine where was a "place where the harmful event occurred or may occur" (in this case violation of protection of a person) as stated in article 5, paragraph 3 Regulation Brussels I (article 7 paragraph 2 Brussels I bis).

CJEU took over previous judgement on spreading of a printed matter, which interpreted the phrase "place where the harmful event occurred or may occur" as a place which relates to place of causal event and also to a place where injury occurred.

According to CJEU it is necessary to adapt the interpretation so the injured party that suffered violation of personal rights using the internet can bring a suit and demand full compensation. For the purpose of the assessment of this case CJEU established another decisive criterion for determining court jurisdiction, so called criteria of center of interests of an injured party. Such place can be for example place of residence, other places with a tight bond to other member state, place of work etc. The court, whose jurisdiction is determined on basis of center of interest's criteria, is authorized to decide on a full compensation. 


\section{Wintersteiger AG v. Products 4U Sondermaschinenbau GmbH (C-523/10)}

CJEU made a statement in the judgement on prejudicial question regarding article 5, paragraph 3 regulation Brussels I (article 7 paragraph 2 Brussels I bis) in the dispute Wintersteiger $A G$ v. Products $4 U$ Sondermaschinenbau GmbH. Subject matter of the dispute was a lawsuit of an Austrian company Wintersteiger demanding a ban of using Wintersteiger trademark by German company Products $4 \mathrm{U}$ as a keyword on a website of a payable search optimization provider.

In terms of a continuity with previous interpretations of article 5, paragraph 3 regulation Brussels I (article 7 paragraph 2 Brussels I bis) we have concluded that "place where the harmful event occurred or may occur" means a place, where damage occurred and also causal event took place, so the defendant can be sued by the plaintiff at the court, whose jurisdiction is established by means of above mentioned criteria.

For the purpose of identifying the place, where damage by using the internet occurred, we need to distinguish between encroaches to intellectual property and encroaches to industrial property. Unlike protection of a person, which can demand protection of a personal rights in every member state, protection provided by trademark is limited on area of a specific member state, so the owner cannot demand this protection in other member states. The risk that a damage will arise, exists under the condition that the right is protected in a member state. Identification of a place where the damage took place in order to establish court jurisdiction also depends on choosing a court which is the most suitable for the particular case. In case of jurisdiction of disputes concerning violations of a trademark rights, the most suitable court is the one residing in a member state, which protects this particular right. Those courts can best assess, whether there was a violation of trademark right or not.

CJEU had to acknowledge the fact that in cases of a place of causal event leading to violation of rights of a national trademark due to its unauthorized use on the internet, based on fact that limitation of protection of national trademark cannot exclude court jurisdiction of other courts than the ones residing in the member state where the trademark was registered. In case of violation of rights using a keyword that is identical to a trademark registered in a member state which can happen by using advertisement on a website, the causal event would be that the advertiser has initialized the technical process which leads to displaying of the advertisement, not only displaying of the advertisement itself. Initialization of a technical process which will lead to a displaying of an advertisement, will actually happen on a server of a web browser provider. But in view of predictability of court jurisdiction, location of the server cannot be acknowledged as a "place where harmful event occurred" stated in article 5, paragraph 3 regulation Brussels I (article 7 paragraph 2 Brussels I bis). That means that disputes concerning violation of rights could be also brought before court in member state where the advertiser is residing. On top of that, court, whose jurisdiction was established by criteria of causal event can more easily obtain evidence and more effectively organize the dispute. 


\section{WIPO Joint Recommendation}

We may ask if there are some principles of determination international court jurisdiction in internet cases which can be used worldwide. It seems to be obvious that national courts tend to find a link between commercial activity on the internet and the territory of each particular state. The deeper is the link, more willing are courts to determine their own jurisdiction. In practice it can be very helpful to use WIPO Joint Recommendation Concerning Provisions on the Protection of Marks, and Other Industrial Property Rights in Signs, on the Internet. ${ }^{3}$ According to this WIPO Recommendation in determining whether use of a sign on the Internet has a commercial effect, the court shall take into account all relevant circumstances which include:

* the level and character of commercial activity of the trademark user in the relation to the territory (e.g. whether the user is actually serving customers; whether the user has stated, that he does not intend to deliver the goods or services to customers located in the territory; whether the user offers post-sales activities, such as warranty),

* the connection of an offer of goods or services on the internet with the territory (e.g. whether the goods or services offered can be lawfully delivered; whether the prices are indicated in the official currency used in the territory),

* the connection of the manner of use of the sign on the internet with the territory (e.g. whether the sign is used in conjunction with means of interactive contact which are accessible to internet users in the territory; whether the user has indicated, in conjunction with the use of the sign, an address, telephone number or other means of contact in the territory; whether the sign is used in connection with a domain name referring to the territory; whether the text used in conjunction with the use of the sign is in a language predominantly used in the territory).

Any of these factors shall serve as guidelines to assist for determination whether the use of a sign has produced a commercial effect in the territory and not as pre-conditions for reaching that determination. Determination in each case will depend upon the particular circumstances of that case.

\section{Conclusion}

In the past few years unlawful use of trademarks on the internet has become more frequent. As regards trademarks the vast majority of cases in this field concern domain names. Nonetheless, there are examples of other forms of unlawful use of trademark as well. Private international law raises some of the most difficult questions in this area. First, it is necessary to decide which court has jurisdiction in unlawful use of trademarks cases online. Secondly, once the court jurisdiction is established, there is a need to determine what substantive law the court has to apply.

\footnotetext{
${ }_{3}^{3}$ Available online at https://www.wipo.int/edocs/pubdocs/en/marks/845/pub845.pdf [07-02-2019].
} 
Collision of two principles, territorial jurisdiction of trademarks and a global range of the internet, went through a development in case of international court jurisdiction. However, this development did not initiate a need to change current procedural law. Original, strictly extensive interpretation of impacts of acting on the internet, is based on a criterion of availability. That consists in stating that damage can potentially happen on all locations, where the website is available. This interpretation would lead to so called forum shopping, therefore purpose-built choosing of a court, and would mean unpredictability in establishing court jurisdiction. On the other hand, limitation of a territorial jurisdiction of a trademark cannot exclude international court jurisdiction of a court from abroad. Such behavior would be too restrictive, given the global range of internet communication and would lead to denial of a court protection. Nowadays, courts in different countries move within these extremes and establish jurisdiction based on intensiveness of a link between activity which is subject matter in a dispute and an area where the trial should take place. In American case-law we can find zippo test, effects test or a targeting test. In case law of CJEU aim criteria, criteria of center of interests and criteria of a place where the harmful event occurred or may occur. With regard to trademarks, all those criteria have something in common, which is a will of an originator, that his actions will have business effects in a specific country. According to authors of this article, there is no need to change conflicting rules of law based on a principal of lex loci protections, therefore application of a substantive law of a country, to which protection of a trademarks applies. Unpredictability of court judgements and interference to a trial itself should not be a factor due to substantive law harmonization in EU. Thereof European and American courts lead up to finding a link, between a territory and actions on the internet through commercial effects (WIPO Joint recommendation seems to be very useful for this purpose). For those reasons it is not necessary to look for new border determinations, for example location of an information on the internet, because in term of an application of a substantive law, they are irrelevant. Relevant fact is unlawful use of a trademark (on a website, in a keyword of a search engine, in a domain name etc.). From a technical point of view, it is basically information transfer which can be difficult to trace because of its location and transfer of a data on the internet (divided and decentralized data transfer, location on a different server, deposition in cache computer memory). Moreover, content of an information, basically wrote in binary code, is easily alterable. It is necessary to evaluate the given fact from a point of view of a specific person, who places the information on the internet. Such action has to be qualified as a use of a trademark within trademark law. 


\section{References}

Akehurst, M. (1972). Jurisdiction in International Law. British Yearbook of International Law, 46(145), 145-257.

Bogdan, M. (2011). Website Accessibility as Basis for Jurisdiction Under the Brussel I Regulation. Masaryk University Journal of Law and Technology, 5(1), 1-9.

Goldsmith, J. (1998). The Internet and the Abiding Significance of Territorial Sovereignty. Indiana Journal of Global Legal Studies, 5(2), 475-491.

Johnson, D., Post, D. (1996). Law and Borders - The Rise of Law in Cyberspace. Stanford Law Review. Stanford University School of Law, 48(1), 1367-1402.

Lessig, L. (2006). Code. Version 2.0. New York: Basic Books.

Mills, A. (2009). The confluence of public and private international law: justice, pluralism and subsidiarity in the international constitutional ordering of private law. Cambridge: Cambridge University Press.

Polčák, R. (2007). Právo na internetu: spam a odpovědnost ISP. Brno: Computer Press.

Rozehnalová, N., Tyč, V. (2003). Evropský justiční prostor v civilních otázkách. Brno: Masarykova univerzita.

Rozehnalová, N. (2010). Závazky ze smluv a jejich právní režim: se zvláštním zřetelem na evropskou kolizní úpravu. Brno: Masarykova univerzita.

Svantesson, D. B. (2016). Private international law and the Internet (3rd ed.) Alphen aan den Rijn: Kluwer Law International.

Wang, F. F. (2010). Internet jurisdiction and choice of law: legal practices in the EU, US and China. Cambridge: Cambridge University Press.

World Intellectual Property Organization (2001). Joint Recommendation Concerning Provisions on the Protection of Marks, and Other Industrial Property Rights in Signs, on the Internet. Retrieved February 7, 2019, from https://www.wipo.int/edocs/pubdocs/ en/marks/845/pub845.pdf. 